\title{
Analysis of Sediment Transport on the Upstream Code River, Indonesia
}

\author{
Jazaul Ikhsan*, Reni Kurniati, Puji Harsanto, Nursetiawan \\ Department of Civil Engineering, Universitas Muhammadiyah Yogyakarta P.O Box 55183, Yogyakarta, Indonesia
}

Received February 25, 2020; Revised June 24, 2020; Accepted July 7, 2020

Copyright $\odot 2020$ by authors, all rights reserved. Authors agree that this article remains permanently open access under the terms of the Creative Commons Attribution License 4.0 International License

\begin{abstract}
Purpose: The Code River is one of the pathways from debris flows of Mount Merapi that crosses the centre of Yogyakarta City, Indonesia. Along the Code River, there are densely populated areas, mainly when the river flows through the centre of Yogyakarta City. Mount Merapi is one of the most active volcanos in Indonesia, also in the world. Based on the data, the volcano usually erupts in 3-year periods for a small scale and nine years for a large scale. Its eruptions produce a considerable material. The eruption material from Mount Merapi carried by the debris flows affected the sedimentation process in rivers that originated in the volcano, particularly the Code River. This research was conducted to find out the amount of sediment transport and its impact on the upstream area of the Code River. Methodology: Methods used in the determination of sediment transport at Code River are Frijlink, Meyer Petter Muller, and Einstein method. Results: Based on the results, it shows that according to the Frijlink method, the sediment transport occurred is $19.79-85.43 \mathrm{~m}^{3} /$ day and the sediment transport of MPM method is $15.06-77.23 \mathrm{~m}^{3} /$ day, whereas the sediment transport of Einstein's method is 8.89 - $70.36 \mathrm{~m}^{3} /$ day. The results also showed that the calculation of sediment transport using the three methods, a phenomenon of erosion took place at a location between observation points 1 and 2 , and a phenomenon of sedimentation occurred at a location between observation points 2 and 3.
\end{abstract}

Keywords Code River, Sediment Transport, Mount Merapi, Frijlink Method

\section{Introduction}

The river is a source of life that functions as a water resource, recreation, irrigation, transportation and so on. In 2010, the enormous eruption at Mt Merapi occurred and vomited a lot of materials. After the eruption, the sediments of cold lava floods then saved in the upstream of Mt Merapi (Ikhsan, J., 2014). According to Rahayu et al. (2014), there are two dangers of volcanic eruptions, that is primary hazards which are directly perceived by residents such as hot clouds, and secondary hazards that are perceived after eruption occurs in the form of cold lava flood that can cause land and settlement damage. According to Ardana and Purwanto (2013), cold lava floods as a secondary hazard can occur when the intensity of rainfall high, materials eruption then transported following the river channel.

The Code River is one of the pathways cold lava floods of Mount Merapi and was included in the main river of the Opak watershed that crosses the centre of Yogyakarta City and densely populated areas. The densely populated areas around the Code River are considered to be very unsafe and worried will affecting the areas if cold lava floods occur in the future. According to Ikhsan and Fahmi (2015), damage to cold lava floods on the Opak River line can result in changes in the flow of the river and surrounding ecosystems.

According to Mao (2018), the transport of coarse sediment during flooding often shows very emotional changes in flow field changes, geometry channels, bedforms, and sediment supply conditions. Mount Merapi is one of the most active volcanos in Indonesia, also in the world. Based on the data, the volcano usually erupts in 3 -year periods for a small scale and nine years for a large scale (Ikhsan, et al., 2009; Ikhsan, et al., 2010). Its eruptions produce a huge material. Based on the previous researches, it is known that the sediment originated from the material eruption of cold lava floods Mount Merapi. The eruption material from Mount Merapi carried by the debris flows affected the sedimentation process in rivers that originated in the volcano, particularly the Code River. And according to the BBWSSO RENSTRA ("Rencana Strategies Balai Besar Wilayah Sungai Serayu Opak"), the eruption is estimated to still save a mass of the material of 150 million $\mathrm{m}^{3}$, after the big eruption in 2010 . According to 
Syarifuddin et al. (2017), after the 2010 eruption, more than 50 volcanic debris flow (lahar) events occurred during the rainy season of 2010-2011 at Mount Merapi, Indonesia.

The process of sedimentation is soil carried away by water flow and settles in a place because the discharge flow is slowed or stopped. The discharge flow is one of the factors that influence the sedimentation process, the lower the discharge flow the less sediment transport, while the higher the discharge flow, the higher the sediment transport load (Sembiring et al., 2014). According to Sudira et al. (2013), the sedimentation process includes the process of erosion, transport, and deposition as well as compaction by sediment itself. According to Kusnan in Pangestu and Haki, (2013), a large volume of sediment depends on the change of the flow velocity, due to changes in the dry season and rainy season, and changes that are influenced by the human activity itself. Usman (2014), explains that the definition of sedimentation is the process of deposition of material transported by water, wind, ice, or glaciers. If the capacity of the incoming sediment in a cross-section is equal to the amount coming out, then the river will be called balanced (Sa'ud, 2018). An unequal sediment supply and transport capacity (a river's ability to transport sediment) could create a river to avulse or significantly change its form by eroding or depositing sediment on the bed or banks (Yager et al., 2012). According to Mananoma et al., (2005), the increase in water damage in the form of erosion and sedimentation is caused by changes in environmental function by the rate of population growth and increasing community activities. Human activities and climate change may alter sand or gravel inputs into alluvial rivers, and therefore graded bedload transport can make severe morphological changes (Li et al., 2016). The large amount of sediment from Mt.Merapi can become a threat for people but also benefit because it can be natural resources such as sand mining for a miner (Ikhsan et al., 2009). And the amount of sedimentation caused by cold lava floods is feared will bring a significant impact in the future along the watershed of Code River.

The sediment transport is divided into three classifications bedload, suspended load, and wash load. In this study, sediment transport focuses on bedload transport. Bedload transport refers to the movement of bed sediments along the stream bed by rolling, sliding, or jumping and is dependent on the river's morphological characteristics (Sirdari et al., 2014). Gravel and cobble transport by rivers govern channel change and is essential to geomorphologists and river engineers (Hsu et al., 2011). According to Lemma (2019), predicting bedload transport rates contributes to river management, river engineering works design, accurate knowledge of sediment delivery rates, which benefits sediment-related water resources management. The analysis of sediment transport in this research was conducted to determine the value of the sediment transport that occurs and how it affected the watershed of the Upstream of Code River. With various methods of analysis of sediment transport, the methods used in this research are Frijlink 1952, Meyer Petter Muller 1948, and Einstein 1950.

\section{Material and Methods}

\section{Research Location}

The research was located at the Upstream Code River, Yogyakarta, with a length of $3.5 \mathrm{~km}$. The location is divided into three testing points, that are Kamdanen Bridge with coordinates of $7^{\circ} 43^{\prime} 22.4724^{\prime \prime} \mathrm{N}$ latitudes, $110^{\circ} 23^{\prime}$ 21.5016" E longitudes and elevation 212,526 meters above sea level, Plemburan Bridge with coordinates of $7^{\circ} 44^{\prime}$ 45.4236" S latitudes, $110^{\circ} 22^{\prime} 37.8444 "$ E longitudes and elevation 165,152 meters above sea level, and Ring Road Al-Azhar Bridge with coordinates of $7^{\circ} 45^{\prime} 6.4836^{\prime \prime} \mathrm{S}$ latitudes, $110^{\circ} 22^{\prime} 29.8704 "$ E longitudes and elevation 151.218.meters above sea level. Figure 1 presents the research location for each location on the Code River. 


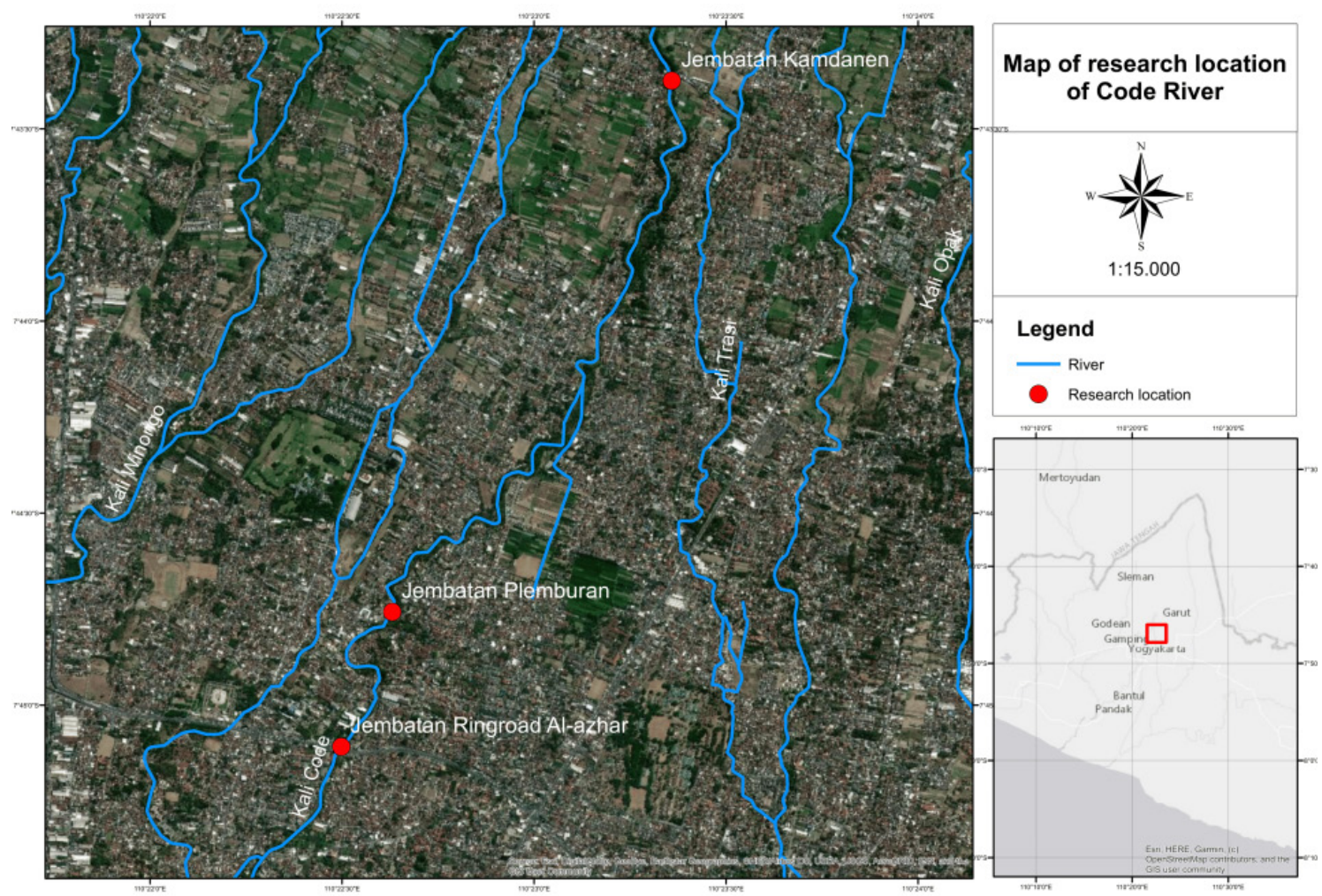

Figure 1. Map of research location of Code River, Yogyakarta, Indonesia

\section{Hydrometry}

Hydrometry is the science of river measurement in the field. Measurement data obtained are velocity, river width, river depth, hydraulic radius, slope, and river discharge. River measurement steps in this study follow the river measurement procedure in Bambang Triatmodjo's book Hydrology Applied about river hydrometry. Measurements of river velocity are obtained by dividing the distance by time from point A to point B using the buoy method. From three research sites, the river velocity has different values, from Kamdanen Bridge to Plemburan Bridge, there was an increase in the speed of flow. At the same time, there is a decrease in the velocity of flow from the Plemburan Bridge to the Ringroad AL-Azhar Bridge. Data of river width and river depth are then processed and obtained a cross-section of rivers, of the three research locations, the cross-section of waterways is known to vary. All data is then used in the analysis of sediment calculations.

\section{Laboratory Tests}

Tested of sediment transport carried out in the Geotechnical Laboratory of Universitas Muhammadiyah Yogyakarta. Tests carried out are specific gravity testing and granular gradation analysis. Data obtained during the accurate gravity test is the value of the specific gravity and type of soil from sediments taken in the field. Of the amount of the specific gravity then obtained the value of the mass density soil, where the value is used in the calculation of sediment transport. The accurate gravity test is carried out according to the standards of ASTM D 854-10. While the test results from granular gradation analysis obtained the percentage of filter pass $90 \%, 65 \%$, $50 \%$, and $35 \%$, and also the median diameter value, tests are carried out using standards from SNI 03-1968-1990.

\section{Result and Discussion}

\section{Frijlink 1952}

In 1952 Frijlink derived the equation for sediment transport as follows:

$$
\mathrm{Tb}=d m \cdot \sqrt{g \cdot \mu \cdot R \cdot I} \cdot 5 e^{-0,27 \frac{\Delta d m}{\mu \cdot R \cdot I}}
$$

where:

$$
\begin{aligned}
& \mathrm{Tb} \quad=\text { Sediment Transport }\left(\mathrm{m}^{3} / \mathrm{m} . \mathrm{s}\right) \\
& \mathrm{dm} \quad=\text { Diameter granules (D50) } \\
& \mathrm{R}=\text { The hydraulic radius (m) } \\
& \mathrm{g}=\text { The acceleration due to gravity } \\
& \mathrm{I}=\text { Slope } \\
& \mu=\text { Ripple Factor }
\end{aligned}
$$

The Frijlink equation is a simple fit of Meyer-Peter and Mueller and Einstein Equations (Haddadchi et al., 2013). Analysis calculation of the sediment transport on the Upstream Code River using the Frijlink 1952 Eq. (1) obtained the value of the sediment transport per second and day in Table 1. It is known from the results of the 
calculation analysis, and the most sediment transport value is found in along river the Plemburan Bridge, this indicates that along the river from the Kamdanen to the Plemburan Bridge, there was an increase in sediment transport derived from erosion of the river by $49.89 \mathrm{~m} 3 /$ day. Whereas on the Al-Azhar Ringroad Bridge, the value of sediment transport decreased, this indicates a reduction in the amount of sediment transport due to sedimentation by $65.64 \mathrm{~m}^{3} /$ day along the Plemburan Bridge to the Al-Azhar Ringroad Bridge. The result of sediment transport using the Frijlink method is shown in Figure 2.

Table 1. Sediment transport on the Upstream CodeRiver Frijlink method

\begin{tabular}{cccc}
\hline \multirow{2}{*}{ No } & \multirow{2}{*}{ Location } & \multicolumn{2}{c}{ Frijink 1952 } \\
\cline { 3 - 4 } & & $\mathbf{m}^{3} / \mathbf{s}$ & $\mathbf{m}^{3} / \mathbf{d a y}$ \\
\hline 1 & Kamdanen Bridge & 0.00004114 & 35.544 \\
2 & Plemburan Bridge & 0.00007848 & 85.433 \\
3 & Al-azhar DIY Bridge & 0.00001273 & 19.794 \\
\hline
\end{tabular}

\section{Meyer Petter Muller 1948}

$$
\text { ww. } \frac{Q s}{Q} \cdot\left(\frac{K s}{K r}\right)^{\frac{3}{2}} \cdot h \cdot . I=A^{\prime \prime} \cdot \gamma s^{\prime \prime} \cdot d m+B^{\prime \prime}\left(\frac{m w}{g}\right)^{\frac{1}{3}} \cdot g s^{\prime \prime \frac{2}{3}}
$$

where:

$$
\begin{array}{ll}
\text { gs" } & =\text { Sediment Transport }(\mathrm{Kg} / \mathrm{m} . \mathrm{s}) \\
\text { A" } & =0.047 \\
\text { B" } & =0.25 \\
\gamma \mathrm{s} " & =\gamma \mathrm{s}-\gamma \mathrm{w}
\end{array}
$$

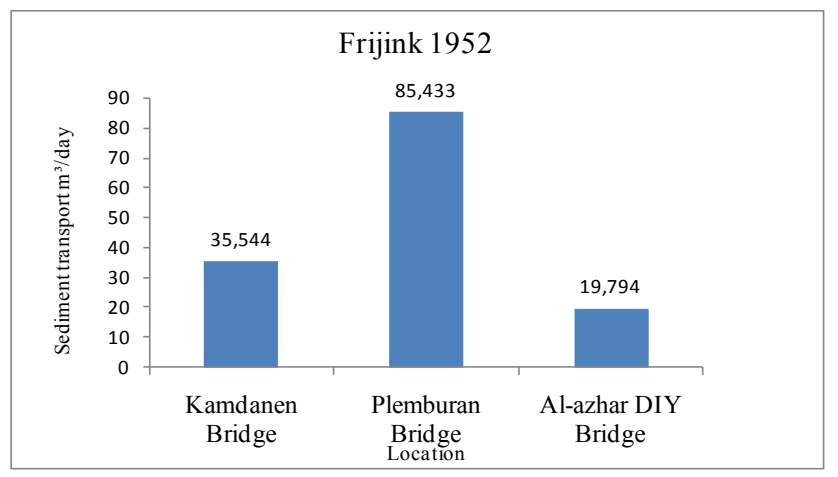

a.

$$
\begin{array}{ll}
\mathrm{dm} & =\text { Diameter granules, D50- D60 } \\
\mathrm{Qs} / \mathrm{Q} & =\mathrm{Rb} / \mathrm{h} \\
\mathrm{Ks} / \mathrm{Kr} & =\text { Ripple Factor }
\end{array}
$$

The Meyer Petter Muller Equation assumed the hydraulic roughness is known. The equation is suitable to estimate the transport rate in streams where the composition of the bed material and the flow conditions are known (Haddadchi et al., 2013). From the analysis of the Meyer Petter Muller method Eq. (2), the results obtained in Table 2 are not much different from the results of the calculation analysis using the Frijlink and the Einstein method. The only difference is the sediment transport values for each method. It is known that the highest sediment transport value is on the Plemburan Bridge causes riverbed erosion of $42.69 \mathrm{~m}^{3}$ / day along the Kamndanen to the Plemburan Bridge. And the sedimentation of $61.47 \mathrm{~m}^{3} /$ day along the Plemburan to the Al-Azhar Bridge. The value of erosion and sedimentation is obtained from the difference in sediment transport received and exited in each location. The value of erosion and sedimentation, according to the MPM method, is shown in Figure 3.

Table 2. Sediment transport on the Upstream CodeRiver Meyer Petter Muller method

\begin{tabular}{cccc}
\hline \multirow{2}{*}{ No } & Location & \multicolumn{2}{c}{ MPM 1948 } \\
\cline { 3 - 4 } & & $\mathbf{m}^{3} / \mathbf{s}$ & $\mathbf{m}^{3} / \mathbf{d a y}$ \\
\hline 1 & Kamdanen Bridge & 0.00044061 & 38.069 \\
2 & Plemburan Bridge & 0.00089386 & 77.230 \\
3 & Al-azhar DIY Bridge & 0.00017429 & 15.059 \\
\hline
\end{tabular}

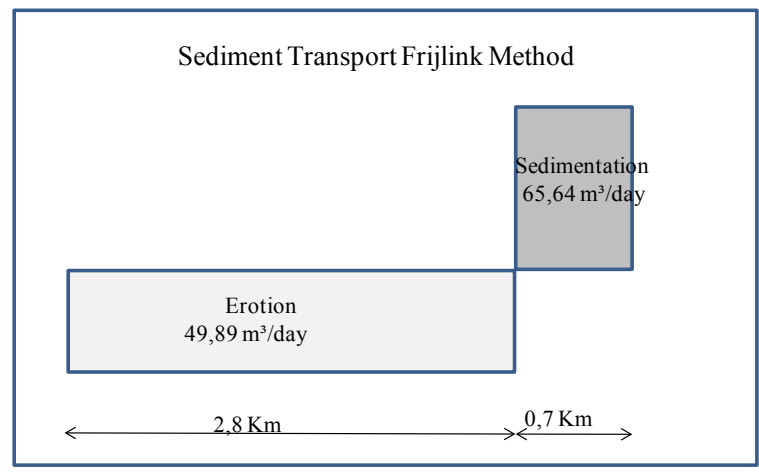

b.

Figure 2. a. Diagram sediment transport the Upstream Code River Frijlink method, b. Illustration transport sediment Frijlink method 


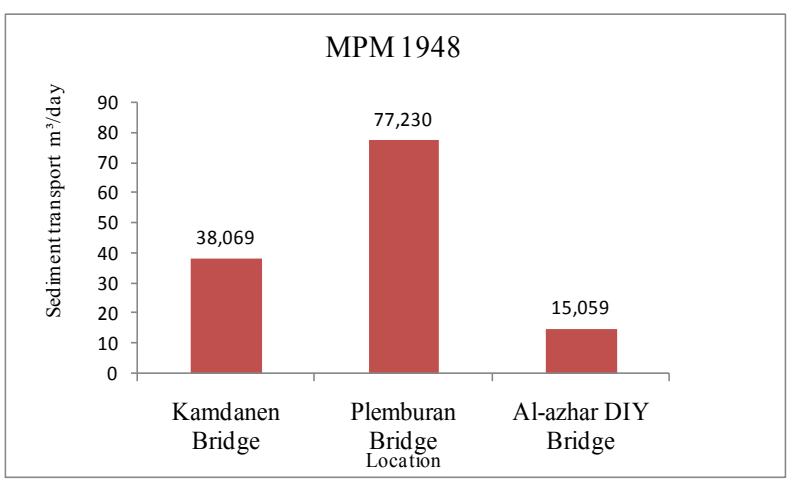

a.

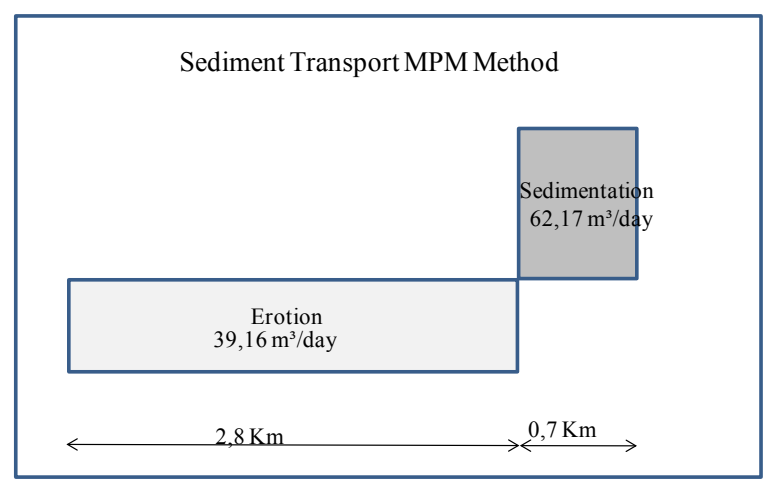

b.

Figure 3. a. Diagram transport sediment the Upstream Code River MPM method,b. Illustration transport sediment MPM method

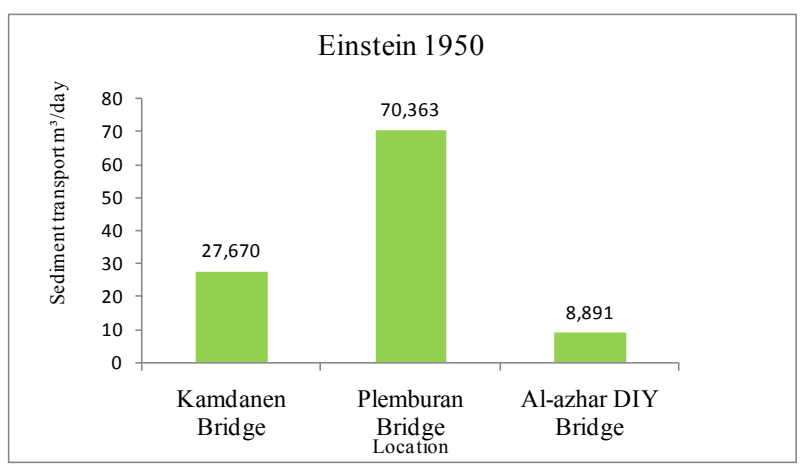

a.

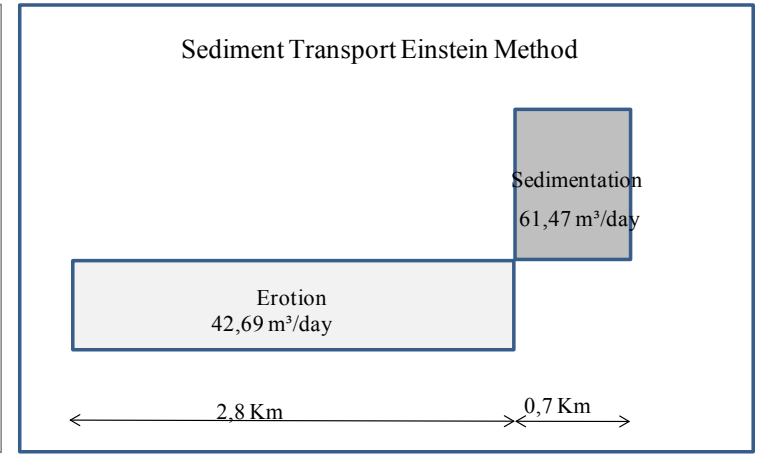

b.

Figure 4. a. Diagram transport sediment the Upstream Code River Einstein method,b. Illustration transport sediment Einteinmethod

\section{Einstein1950}

$$
\mathrm{i}_{\mathrm{B}} \mathrm{q}_{\mathrm{B}}=\varphi_{*} \cdot i_{b} \cdot \gamma_{s}(g \cdot D)^{\frac{3}{2}}\left(\frac{\gamma_{s}-\gamma_{w}}{\gamma_{w}}\right)^{1 / 2}
$$

where:

$\mathrm{iB}=$ Base free parts with certain granular sizes.

$\mathrm{qB}=$ Baseload rate in weight per unit time and unit width of the groove $(\mathrm{kg} / \mathrm{m} . \mathrm{s})$

$\mathrm{ib}=$ Specific grain size fraction

$\mathrm{D}=$ Specific size grain diameter. $(\mathrm{m})$

Einstein approached the basic sediment transport equation with statistical theory, although at first, it did not take into account the effect of a basic configuration of the channel. Only in 1950, he perfected the equation by including the impact of the basic configuration. According to Einstein's method in Eq.(3), sediment transport on the Kamdanen Bridge occurred by $27.67 \mathrm{~m}^{3}$ / day. On the Plemburan Bridge by $70.36 \mathrm{~m}^{3} /$ day, an increase in the amount of sediment transport was recorded at $39.16 \mathrm{~m}^{3} /$ day. It's caused by erosion of the riverbed along the Kamdanen Bridge to the Plemburan Bridge. Whereas on the Al-Azhar Ringroad Bridge, sediment transport occurred by $8.89 \mathrm{~m}^{3} /$ day, the decrease in sediment transport amounted to $62.17 \mathrm{~m}^{3}$ / day caused sedimentation along the Plemburan Bridge to the AL-Azhar Ringroad Bridge. The value of erosion and sedimentation, according to the MPM method, is shown in Figure 4, and the result of sediment transport by the Einstein method is shown in Table 3.

Table 3. Sediment transport on the Upstream CodeRiver Einstein method

\begin{tabular}{cccc}
\hline \multirow{2}{*}{ No } & \multirow{2}{*}{ Location } & \multicolumn{2}{c}{ Einstein 1950 } \\
\cline { 3 - 4 } & & $\mathbf{m}^{3} / \mathbf{s}$ & $\mathbf{m}^{\mathbf{3}} / \mathbf{d a y}$ \\
\hline 1 & Kamdanen Bridge & 0.00032 & 27.670 \\
2 & Plemburan Bridge & 0.00081 & 70.363 \\
3 & Al-azhar DIY Bridge & 0.0001 & 8.891 \\
\hline
\end{tabular}


Table 4. Sediment transport on the Upstream CodeRiver

\begin{tabular}{cccccccc}
\hline \multirow{2}{*}{ No } & \multirow{2}{*}{ Location } & \multicolumn{2}{c}{ Frijink 1952 } & \multicolumn{2}{c}{ MPM 1948 } & \multicolumn{2}{c}{ Einstein 1950 } \\
\cline { 3 - 8 } & & $\mathbf{m}^{3 / \mathbf{s}}$ & $\mathbf{m}^{\mathbf{3} / \mathbf{d a y}}$ & $\mathbf{\mathbf { m } ^ { 3 } / \mathbf { s }}$ & $\mathbf{m}^{\mathbf{3} / \mathbf{d a y}}$ & $\mathbf{m}^{3} / \mathbf{s}$ & $\mathbf{m}^{\mathbf{3} / \mathbf{d a y}}$ \\
\hline 1 & Kamdanen Bridge & 0.00004114 & 35.544 & 0.00044061 & 38.069 & 0.00032 & 27.670 \\
2 & Plemburan Bridge & 0.00007848 & 85.433 & 0.00089386 & 77.230 & 0.00081 & 70.363 \\
3 & Al-Azhar DIY Bridge & 0.00001273 & 19.794 & 0.00017429 & 15.059 & 0.0001 & 8.891 \\
\hline
\end{tabular}

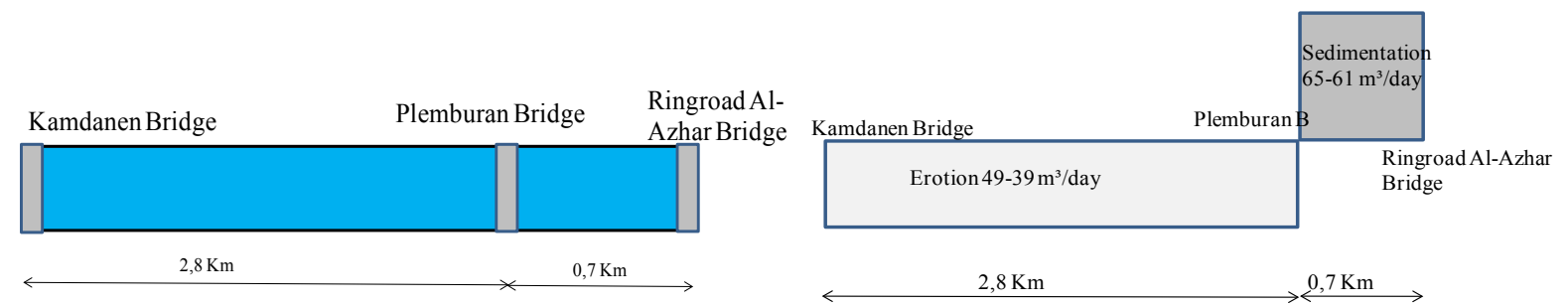

b.

Figure 5. a. Illustration of sedimentation in the Upstream Code River top view, b. Illustration of erosion and sedimentation in the Upstream Code River side view

According to the three methods, the value of sediment transport from each location has a close result. Table 4 shows that sediment transport from the three methods at the Kamdanen Bridge to Plemburan Bridge has sediment transport of $27-38 \mathrm{~m}^{3} /$ day. The results obtained are known there is an addition of sediment from the erosion of the base river or other with a volume of $39-49 \mathrm{~m}^{3} /$ day. Erosion of the riverbed will eventually lead to the erosion of the river cliff, even if the erosion occurs below the bridge, there will be erosion and the impact on the collapse of the bridge.

Whereas the potential sediment transport at the location of Ring road Al-Azhar Bridge is 8.89-19.79 m3/day. With a decrease in the amount of sediment transport, it can be concluded that along the river from the Plemburan towards Ring road Al-Azhar Bridge, there is sedimentation by $62-65 \mathrm{~m} 3 /$ day. A huge amount of river bedload sediment will undoubtedly have an impact on the area around the river flow, and bedload sedimentation affects riverbed siltation. And if the sedimentation gets bigger, it will cause flooding around the watershed. Moreover, if the eruption of Mount Merapi occurs and causes cold lava floods, this will undoubtedly increase the amount of sediment in the river bed and causing massive flooding. If sedimentation is left without maintenance, it can be ensured that in the future it will have an impact around the watershed on the Upstream Code River. Figure 5 presents an illustration of sedimentation in the upstream Code river in top and side views.

Based on the results of the three methods, the tendency of the results obtained is similar. But which of the three methods provides the most accurate value? Some researchers have tried to compare the effects of calculations between sediment equations with measurements in the field. Gomez and Church (1989) evaluated the efficiency of formulas formulated for use in gravel-bed streams with 12-bed load sediment transport. In the experiments, a total of 88 river data sets were used. These river data were gathered from four rivers of gravel beds in the USA. No formula performs consistently well, but the equations of the Bagnold, Schoklitsch, and Einstein yield the highest degree of precision and the least variance from measured river results. Haddadchi et al. (2013), compared the performances of the 12-bed load formula to find the suitable bedload formula for a gravel-bed river with a mild slope. The equations of Engelund and Hansen (1967), Van Rijn (1984a), and Einstein (1950) accurately predicted bedload transportation as a symbolic diameter in this river with the size of the bed content grains. The accuracy of these 12 formulas is Shocklitsch (1950), Meyer-Peter and Mueller (1948), Frijlink (1952), and Einstein (1950), in descending order of bedload grain scale. The higher overall accuracy of a formula does not guarantee that, under all conditions of flow and sediment, the method is superior to the others. A formula's accuracy rating may vary depending on the slope of bed, the diameter of grain size, and other hydraulic and sedimentological details. This implies that without a sufficient number of measurements, we can't predict the discharge of the bedload transport with any degree of reliability.

The conclusion is to determine which suitable equation is used in the Code River; it needs to be compared with measurements in the field. However, to predict the magnitude of sediment transport, the three equations can be used. For disaster risk reduction, such as making flood embankments, the highest result from the three methods is used. But for resource utilization, for example, determining the volume of sand mining, the smallest result from the three formulas can be used. 


\section{Conclusions}

Analysis of sediment transport in the Upstream Code River using the Frijlink method obtained the sediment transport of $35.544 \mathrm{~m} 3 /$ day $-84.869 \mathrm{~m} 3 /$ day. While the MPM method obtained of $15.059 \mathrm{~m} 3 /$ day $-77.230 \mathrm{~m} 3 /$ day. And Einstein method got sediment transport of 8.891 $\mathrm{m} 3 /$ day $-70.363 \mathrm{~m} 3 /$ day. The amount of sediment transport in the Upstream Code River influences changes in the cross-section along the river banks due to erosion and sedimentation, at the point of the Kamdanen to the Plemburan Bridge, there is an increase in the value of sediment transport due to the erosion of the river, while at Plemburan to Al-Azhar Bridge occurs sedimentation caused by a decrease in the amount of sediment transport. The conclusion is to determine which suitable equation is used in the Code River; it needs to be compared with measurements in the field data.

\section{Acknowledgments}

Thanks to the Research, Publication, and Community Service Division, Universitas Muhammadiyah Yogyakarta for its support of this study, and the author's colleagues for help.

\section{REFERENCES}

[1] Ardana, D. M. S., \& Purwanto, T. H. (2013). Determination of evacuation route and impacts of the debris flows of Mount Merapi in Magelang, Central Java. Journal of Bumi Indonesia, 2(2). (in Indonesian)

[2] ASTM D 854-10 for Standard Test Methods for Specific Gravity of Soil Solids by Water Pycnometer

[3] Einstein, H.A., 1950. The bed-load function for sediment transportation in open channel flows. Technical Bulletin, No. 1026, U.S. Dep. of Agriculture, Washington, D.C.

[4] Frijlink, H.C., (1952). Discussion of bedload movement formulas of Kalinske, Einstein and Meyer-Peter and Müller and their application to recent measurements of bedload in the rivers in Holland. Delft Hydraulics, Delft, The Netherlands. X2344/LV.

[5] Gomez, B., \& Church, M. (1989). An assessment of bed load sediment transport formulae for gravel bed rivers. Water Resources Research, 25(6), 1161-1186.

[6] Haddadchi, A., Omid, M.H \& Dehghani, A. A. (2013). Bedload equation analysis using bed load-material grain size. J. Hydrol. Hydromech., 61 (3), 241-249, DOI: 10. 2478/ johh-2013-0031

[7] Hsu, L., Finnegan, N. J., \& Brodsky, E. E. (2011). A seismic signature of river bedload transport during storm events. Geophysical Research Letters, 38(13).

[8] Ikhsan, J., \& Fahmi, A. A. (2015). Study of the effect of debris flows on changes in riverbed material characteristics. SNTT FGDT. Faculty of Engineering UM Makassar. 29 July -1 August 2015 (in Indonesian)

[9] Ikhsan, J., Fujita, M., \& Takebayashi, H. (2010). Sediment disaster and resource management in the Mount Merapi Area, Indonesia. International Journal of Erosion Control Engineering, Vol.3, No.1, 43-52.

[10] Ikhsan, J. (2014). Numerical study of changes in elevation and gradation type of riverbed material. Proceeding of Simposium Nasional Teknologi Terapan (SNTT) II 2014. Faculty of Engineering UM Surakarta, Indonesia (in Indonesia)

[11] Ikhsan, J., Fujita, M., \& Takebayashi, H. (2009). Sustainable sand mining management in Merapi area using groundsills. Disaster Prevention Research Institute Annuals, Kyoto University, No. 52 B, 647-657.

[12] KPU BBWSSO, 2015-2019, Strategic Plan Document, Central Region of Serayu Opak River, Yogyakarta (in Indonesian)

[13] Li, Z., Cao, Z., Liu, H., \& Pender, G. (2016). Graded and uniform bed load sediment transport in a degrading channel. International Journal of Sediment Research, 31(4), 376-385.

[14] Lemma, H., Nyssen, J., Frankl, A., Poesen, J., Adgo, E., \& Billi, P. (2019). Bedload transport measurements in the Gilgel Abay River, Lake Tana Basin, Ethiopia. Journal of Hydrology, 577, 123968.

[15] Mananoma, T., \& Legono, D. (2005). Prediction of sediment transport in the river to control water damage, 1-577 (in Indonesian)

[16] Mao, L. (2018). The effects of flood history on sediment transport in gravel-bed rivers. Geomorphology, 322, 196-205.

[17] Meyer-Peter, E., Mueller, R., 1948. Formulas for bed-load transport. Int. Assoc. Hydraulic Research, 2nd Mtg., Stockholm, 39-64

[18] Pangestu, H., \& Hakki, H. (2013). Analysis of total sediment transport in Dawas river, Musi Banyuasin Regency. Journal of Teknik Sipil dan Lingkungan, 1(1), 103-109. (in Indonesian)

[19] Rahayu, R., Ariyanto, D. P., Komariah, K., Hartati, S., Syamsiyah, J., \& Dewi, W. S. (2014). The impact of the Mount Merapi eruption on the land and its recovery efforts. Caraka Tani: Journal of Sustainable Agriculture, 29(1), 61-72. (in Indonesian)

[20] Sa'ud, I. (2008). Sedimentation prediction in Mas river, Surabaya. Journal of Aplikasi Teknik Sipil, 4(1), 20. (in Indonesian)

[21] Sembiring, A. E., Mananoma, T., Halim, F., \& Wuisan, E. M. (2014). Sedimentation analysis in the estuary of Panasen river. Journal of Sipil Statik, 2(3). (in Indonesian)

[22] Sirdari, Z. Z., Ab Ghani, A., \& HASSAN, Z. A. (2014). Bedload transport of small rivers in Malaysia. International Journal of Sediment Research, 29(4), 481-490.

[23] SNI 03-1968-1990. (1990). About fine and coarse aggregate filter analysis. (in Indonesian) 
[24] Sudira, I. W., Mananoma, T., \& Manalip, H. (2013). Analysis of sediment transport in the Mansahan river. Jurnal Ilmiah Media Engineering, 3(1). (in Indonesian)

[25] Syarifuddin, M., Oishi, S., Legono, D., Hapsari, R.I., \& Iguchi, M. (2017). Integrating X-MP radar data to estimate rainfall induced debris flow in the Merapi volcanic area. Advances in Water Resources, 110, 249-262.

[26] Triatmodjo, B., (2008). Applied hydrology. Yogyakarta:
Beta Offset. (in Indonesian)

[27] Usman, (2014). Sedimentation analysis at the estuary of Komering river in Palembang. Journal of Teknik Sipil dan Lingkungan. 2. 2. (in Indonesian)

[28] Yager, E. M., Turowski, J. M., Rickenmann, D., \& McArdell, B. W. (2012). Sediment supply, grain protrusion, and bedload transport in mountain streams. Geophysical Research Letters, 39(10). 